\title{
Phytoremediation Mechanisms of Heavy Metal Contaminated Soils: A Review
}

\author{
Meriem Laghlimi', Bouamar Baghdad², Hassan El Hadi'1, Abdelhak Bouabdli ${ }^{3}$ \\ ${ }^{1}$ Laboratory of Applied Geology, Geomatic and Environment, Faculty of Sciences Ben M'Sik, \\ University Hassan II, Casablanca, Morocco \\ ${ }^{2}$ Department of Natural Resources and Environment, Hassan II Agronomy and Veterinary Institute, \\ Rabat, Morocco \\ ${ }^{3}$ Department of Geology, Faculty of Science, Ibn Tofail University, Kenitra, Morocco \\ Email: laghlimi.meriem@gmail.com
}

Received 14 July 2015; accepted 14 August 2015; published 17 August 2015

Copyright (C) 2015 by authors and Scientific Research Publishing Inc.

This work is licensed under the Creative Commons Attribution International License (CC BY).

http://creativecommons.org/licenses/by/4.0/

(c) (i) Open Access

\begin{abstract}
Phytoremediation is a green emerging technology used to remove pollutants from environment components. Mechanisms used to remediate soils contaminated by heavy metal are: phytoextraction, phytostabilisation, phytovolatilization and rhizofiltration. The two first mechanisms are the most reliable. Many factors influence the choice of the suitable phytoremediation strategy for soil decontamination. It depends on soil properties, heavy metal levels and characteristics, plant species and climatic conditions. The present review discusses factors affecting heavy metals uptake by plant species, the different phytoremediation strategies of heavy metal contaminated soils and the advantages and disadvantages of phytoremediation and each of its mechanisms.
\end{abstract}

\section{Keywords}

Heavy Metal, Soils, Contamination, Phytoremediation

\section{Introduction}

Heavy metals are the major environmental contaminants and pose a severe threat to human and animal health by their long-term persistence in the environment [1]. The remediation of soils contaminated by heavy metals is a cost-intensive and technically complex procedure [2]-[5]. Conventional remediation technologies are based on biological, physical, and chemical methods, which may be used in conjunction with one another to reduce the contamination to a safe and acceptable level [6]. In spite of being efficient, these methods are expensive, time consuming and environmentally destructive [7] [8]. At the same time they are usually harmful to the natural soil 
environment, and generate large amounts of waste [9]. Recently, phytoremediation, which is an emerging technology, should be considered for remediation of contaminated sites because of its cost effectiveness, aesthetic advantages and long term applicability [10]-[13].

The aim of this paper is to provide a brief view about factors affecting heavy metals uptake by plant species, to discuss the different phytoremediation strategies of heavy metal contaminated soils and the advantages and disadvantages of phytoremediation and each of its mechanisms.

\section{Heavy Metals: Definition and Origins}

Heavy metals are natural constituents of the earth's crust [14] [15]. Their principal characteristics are an atomic density greater than $5 \mathrm{~g} \cdot \mathrm{cm}^{-3}$ [16] [17] and an atomic number $>20$ [14]. The most common heavy metal contaminants are $\mathrm{Cd}, \mathrm{Cr}, \mathrm{Cu}, \mathrm{Hg}, \mathrm{Pb}$, and $\mathrm{Zn}$. From the geochemical point of view, trace elements are metals whose percentage in rock composition does do not exceed $0.1 \%$ [18]. The occurrence of heavy metals in soils can result of two main sources:

Natural source: Heavy metals occur naturally in the soil environment from the pedogenetic processes of weathering of parent materials at levels that are regarded as trace $\left(<1000 \mathrm{mg} \cdot \mathrm{kg}^{-1}\right)$ and rarely toxic [19] [20].

Anthropogenic sources: Human activities, such as mining, smelting, electroplating, energy and fuel production, power transmission, intensive agriculture, sludge dumping, and melting operations, are the main contributor to heavy metal contamination [15] [21]-[23]. Heavy metals in the soil from anthropogenic sources tend to be more mobile, hence bioavailable than pedogenic, or lithogenic ones [19] [24] [25]. The industry of mining and processing metals is a major source of farmland heavy metal contamination [26].

\section{Heavy Metal Phytotoxicity}

Metals are natural components in soil. Based on their role on physiological activities, they can be divided in two groups: 1) Essential heavy metals (Fe, $\mathrm{Mn}, \mathrm{Cu}, \mathrm{Zn}$, and $\mathrm{Ni}$ ) which are micronutrients necessary for vital physiological and biochemical functions of plant growth [1] [27] [28]. They are constituents of many enzymes and other proteins [29] and all plants have the ability to accumulate them from soil solution [30]; 2) Non-essential metals $(\mathrm{Cd}, \mathrm{Pb}, \mathrm{As}, \mathrm{Hg}$, and $\mathrm{Cr}$ ) have unknown biological or physiological function [1] [31] and consequently are non-essential for plant growth.

Both groups are toxic to plants, animals and humans above certain concentrations specific to each element [17] [25] [32]. High contents of both essential and non-essential heavy metals in the soil may inhibit plant growth and can lead to toxicity symptoms in most plants [15] [29] [33] [34]. The general effects of various metals in plant are given in Table 1. However, some plant species have the ability to grow and develop in metalliferous soils such as near to mining sites [35]. Such plants can be used to clean up heavy metal contaminated sites. Willow (Salix viminalis L.), maize (Zea mays L.), Indian mustard (Brassica juncea L.), and sunflower (Helianthus annuus L.) has been found to be highly tolerant to heavy metals [36]. Vetiver grass (Vetiveria zizanioides) showed tolerance to $\mathrm{Pb}$ and $\mathrm{Zn}$ and it can be used for revegetating $\mathrm{Pb} / \mathrm{Zn}$ mine tailings [37]. Populus species are examples of plants widely used to remediate heavy metal contaminated soils [38].

\section{Factors Affecting Heavy Metal Phytoavailability}

Bioavailability and phytoavailability are terms used to describe the degree to which contaminants are available for absorption or uptake by living organisms that are exposed to them [46]-[48]. Plants respond only to the fraction that is "phytoavailable" to them [48] [49]. For heavy metal phytoremediation (and phytoextraction in particular), bioavailability of metals in contaminated soils, is a crucial factor regulating heavy metal uptake by plant roots [50]-[52]. However, metal phytoavailability is a complex phenomenon that is dependent on a cascade of related factors [53].

\subsection{Soil Properties}

\subsubsection{Soil pH}

Soil $\mathrm{pH}$ directly influences the phytoavailability of metals as soil acidity determines the metal solubility and its ability to move in the soil solution [54]. Metal cations are the most mobile under acidic conditions while anions 
Table 1. Functions and effects of heavy metals on plant growth [14] [35] [39]-[45].

\begin{tabular}{|c|c|c|c|}
\hline $\begin{array}{l}\text { Heavy } \\
\text { metals }\end{array}$ & & Functions in plant & Effects on plant \\
\hline \multirow{3}{*}{$\begin{array}{c}\text { Essential } \\
\text { metals }\end{array}$} & $\begin{array}{l}\text { Copper } \\
\text { (Cu) }\end{array}$ & $\begin{array}{ll}\text { - } & \text { Constituent of enzymes; } \\
\text { - } & \text { Role in photosynthesis and several } \\
\text { physiological processes; } \\
\text { - } \\
\text { Involved in reproductive and in determining } \\
\text { yield and quality in crops (disease resistance) }\end{array}$ & $\begin{array}{l}\text { - } \quad \text { Disruption of photosynthesis, plant growth and } \\
\text { reproductive processes; } \\
\text { - } \quad \text { Decreases thylakoid surface area }\end{array}$ \\
\hline & $\begin{array}{l}\text { Nickel } \\
\text { (Ni) }\end{array}$ & $\begin{array}{l}\text { - } \quad \text { Constituent of enzymes } \\
\text { - } \quad \text { Activation of urease }\end{array}$ & $\begin{array}{ll}\text { - } & \text { Reduction of: } \\
\text { - } & \text { seed germination; } \\
\text { - } & \text { protein production; } \\
\text { - } & \text { chlorophyll and enzyme production; } \\
\text { - } & \text { accumulation of dry mass }\end{array}$ \\
\hline & $\begin{array}{l}\text { Zinc } \\
\text { (Zn) }\end{array}$ & $\begin{array}{ll}\text { - } & \text { Constituent of cell membranes; } \\
\text { - } & \text { Component of a variety of enzymes; } \\
\text { - } & \text { DNA transcription; } \\
\text { - } & \text { Involved in reproductive phase and in } \\
& \text { determining yield and quality of crops; } \\
\text { - } & \text { Resistance against biotic and abiotic stress; } \\
\text { - } & \text { Legume nodulation and nitrogen fixation }\end{array}$ & - $\quad$ Reduces nickel toxicity and seed germination \\
\hline $\begin{array}{l}\text { Non- } \\
\text { essential } \\
\text { metals }\end{array}$ & $\begin{array}{l}\text { Chromium } \\
\text { (Cr) }\end{array}$ & - & $\begin{array}{ll}\text { - } & \text { Decreases seed germination, lipid content and } \\
\text { plant growth } \\
\text { - } & \text { Disturb enzyme activities, } \\
\text { - } & \text { Inhibit the DNA-mediated transformation in } \\
\text { microorganisms, } \\
\text { - } & \text { Interfere in the symbiosis between microbes and } \\
\text { plants, } \\
\text { - } & \text { Increase plant predisposition to fungal invasion } \\
\text { - } & \text { Causes decrease in enzyme activity and plant } \\
\text { - growth; } & \text { Produces membrane damage, chlorosis and root } \\
& \text { damage. } \\
\text { - } & \text { Reduces chlorophyll, chlorosis, necrosis; } \\
- & \text { Inhibit root and shoot growth } \\
- & \text { Less biomass production } \\
\text { - } & \text { affecting seed germination }\end{array}$ \\
\hline
\end{tabular}

tend to sorb to oxide minerals in this $\mathrm{pH}$ range [55]. Thus at low $\mathrm{pH}$, metal bioavailability increases as more metals are released into the soil solution due to competition with $\mathrm{H}+$ ions [56] [57]. At high pH, cations precipitate or adsorb to mineral surfaces and metal anions are mobilized [58]-[60]. At neutral or alkaline pH, most of the metals in soil are not available to plants, especially $\mathrm{Pb}$ and $\mathrm{Cr}$ are inherently immobile [61].

\subsubsection{Soil Texture}

Texture reflects the particle size distribution of the soil and thus the content of fine particles like oxides and clay [62]. Particle size distribution can influence the level of metal contamination in a soil. Fine particles $(<100 \mu \mathrm{m})$ are more reactive and have a higher surface area than coarser material. As a result, the fine fraction of a soil often contains the majority of contamination [58] [62] reported that the fine textured soils contain higher amounts of $\mathrm{Pb}\left(3889 \mathrm{mg} \cdot \mathrm{kg}^{-1}\right.$ ) and coarse textured soil contains (530 $\mathrm{mg} \cdot \mathrm{kg}^{-1}$ ) lower amount of $\mathrm{Pb}$.

\subsubsection{Soil Organic Matter}

Soil organic matter is frequently reported to have a dominant role in controlling the behavior of trace metals in the soil [62] [63]. The organic matter is one of the factors that may reduce the ability of metals to be phytotoxic in the soil due to metal-organic complexation [64]. The presence of organic carbon increases the cation exchange capacity of the soil which retains nutrients assimilated by plants [65]. Increasing the amount of organic matter in the soil helps to minimize the absorption of heavy metals by plants. Land rich in organic matter ac- 
tively retains metallic elements [66]. Soils with relatively low organic matter concentration are more susceptible to contamination by trace elements [67]. Compost amendments to contaminated soils containing labile elements reduce the overall bioavailabilities of metals due to sorption processes [68].

\subsubsection{Redox Potential}

The redox potential is one of the most soil properties that affect changes metal speciation [69]. Redox potential in soil is established by oxidation-reduction reactions resulting from microbial activity [25] [66]. These redox reactions convert contaminants into non-hazardous or less toxic compounds that are more stable, less mobile and/or inert [70]. However, in soil environments, these reactions tend to be relatively slow [67]. Lack of oxygen in the soil causes start-up and increase the mobility of the large part of heavy metals [66].

\subsubsection{Root Zone}

Plant root can influence heavy metal phytoavailability [54] by modifying the soil properties in the rhizosphere [68]. The plant enzymes exuded from the roots should play a key role in the transformation and chemical speciation of heavy metals in soils, which facilitate their uptake by plant [71]-[73]. Plant root activities that potentially increase metal solubility and may change heavy metal speciation include acidification/alkalinisation, modification of the redox potential, exudation of metal chelants and organic ligands [74]-[76]. However, the process of root exudation and composition of exudates remains poorly understood for most of the environmentally relevant heavy metals [61] [73] showed that the increased mobility of heavy metals was not necessarily associated with their increased uptake in plants.

\subsection{Heavy Metal Properties}

The mobility of trace metals, their bioavailability and related eco-toxicity to plants depend strongly on their specific chemical forms [77]. Forms of occurrence of heavy metals in soil significantly influence their mobility. The most mobile elements include the $\mathrm{Cd}$, $\mathrm{Zn}$ and Mo, while the least mobile are $\mathrm{Cr}$, $\mathrm{Ni}$ and $\mathrm{Pb}$ [66]. Soil pH influences heavy metal mobility. In soils with low $\mathrm{pH}$, metal mobilty decreases in the order: $\mathrm{Cd}>\mathrm{Ni}>\mathrm{Zn}>\mathrm{Mn}>$

$\mathrm{Cu}>\mathrm{Pb}$. According to their phyto-availability, [78] have defined four groups of heavy metal (cited by [47]):

- weakly soluble in soil, absorbed by plants in trace amounts (Cr, Ag);

- elements relatively easily absorbed by roots but weakly transported to shoots (Hg, $\mathrm{Pb})$;

- elements easily absorbed and transported to shoots (Zn, $\mathrm{Cu}, \mathrm{Ni})$;

- elements posing a risk to the food chain (Co, Cd).

However, the effect of $\mathrm{pH}$ on the mobility of metallic elements in the soil is highly variable, depending on the content and type of organic matter [66]. Heavy metals in the solid phase of organic-amended soils occur in various chemical forms, including exchange sites, specific adsorption sites, occluded or adsorbed on to soil oxides, biological residues and substituted into primary and secondary minerals [79]. The chemical speciation of heavy metals determines their bioavailability. It is related to the different natures of the metals, their bonding strength, and either in free ionic form or complexed by organic matter, or incorporated in the mineral fraction of the sample [63].

\subsection{Plants Species}

Plant species differ widely in their ability to accumulate heavy metals [80]. Many authors concluded that concentrations of metals in plants growing in the same soil vary between species and even between genotypes of a species [42] [81]. Some of the mechanisms, which may be responsible for plant species differences in metal concentrations, have been identified. These mechanisms include differences in: 1) root architecture; 2) water use efficiency; 3) rhizosphere chemistry; 4) expression and affinity of root surface transporter proteins for metals; 5) xylem loading of metals and translocation within the plant [82]. Also, the age and the growth stage of the plant can affect concentration of metals in plants [54] [80].

\section{Phytoremediation}

\subsection{Definition and Concept}

Phytoremediation can be defined as the process, which uses green plants for the relief, transfer, stabilization or 
degradation of pollutants from soil, sediments, surface waters, and groundwater [54] [83] [84]. Some plant roots can absorb and immobilize metal pollutants, while other plant species have the ability of metabolizing or accumulating organic and nutrient contaminants. Multifarious relationships and interactions between plants, microbes, soils and contaminants make these numerous phytoremediation processes possible.

The term phytoremediation, from the Greek phyto, means "plant”, and the Latin suffix remedium, "able to cure” or "restore” [44]. This concept was first proposed by Chaney (1983) and then developed through the study of plant species ability to remove pollutants from environment components. It can be used for a wide range of organic [10] and inorganic contaminants [44]. Phytoremediation processes are most effective where contaminants are present at low to medium levels, as high contaminant levels can inhibit plant and microbial growth and activity [85]. Mechanisms involved in the uptake, translocation, and storage of micronutrients are the same involved to translocate and storage heavy metals [1].

\subsection{Mechanisms of Phytoremediation}

Phytoremediation is a general term including several processes, in function of the plant-soil-atmosphere interactions. For heavy metal contaminated soil, four processes of phytoremediation are recognized. Phytoextraction, phytostabilisation, phytovolatilization and rhizofiltration. The two first mechanisms are the most reliable. The different forms of phytoremediation require different general plant characteristics for optimum effectiveness [86]. Table 2 summarizes definition and principle characteristics of each process.

\subsection{Advantages and Limitations of Phytoremediation Mechanisms}

Phytoremediation, like other remediation technologies, has a range of both advantages and disadvantages. The most positive aspect of using phytoremediation is as follow: 1) more cost-effective; 2) more environmentally friendly; 3) applicable to a wide range of toxic metals and 4) more aesthetically pleasing method. On the other hand, phytoremediation presents some limitations. It is a lengthy process, thus it may take several years or longer to clean up a site and it is only applicable to surface soils. Advantages and disadvantages of using phytoremediation for remediation a heavy metals contaminated area and each mechanism are shown in Table 3 and Table 4.

\section{Plant Selection Considerations}

Plant species for phytoremediation are selected based on their root depth, the nature of the contaminants and the soil, and regional climate. The root depth directly impacts the depth of soil that can be remediated [83]. It varies greatly among different types of plants, and can also vary significantly for one species depending on local conditions such soil structure, depth of a hard pan, soil fertility, cropping pressure, contaminant concentration, or other conditions [86]. The cleaning depths are approximately $<3$ feet for grasses, $<10$ feet for shrubs and $<20$ feet for deep rooting trees. The nature of on-site contaminants is a principal factor in the selection of a plant for phytoremediation [103].

It has been reported that for phytoremediation, grasses are the most commonly evaluated plants [104]. They have been more preferable in use for phytoremediation because compared to trees and shrubs, herbaceous plants, especially grasses, have characteristics of rapid growth, large amount of biomass, strong resistance, effective stabilization to soils and ability to remediate different types of soils [54]. They are pioneers and usually are adapted to adverse conditions such as low soil nutrient content, stress environment and shallow soils [105]-[109]. The large surface area of their fibrous roots and their intensive penetration of soil reduces leaching, runoff, and erosion via stabilization of soil and offers advantages for phytoremediation [110]. Wild plants such as grasses can produce closures above ground quickly and reduce dispersion the dust of tailings [111].

Shrubs and trees produce extensive canopy cover and produce deep roots to prevent erosion in the long term. In addition, shrubs or trees provide high nutrient to the grass while lowering water stress and improve soil physical properties [111] [112]. Many trees can grow on land of marginal quality, have massive root systems, and their above-ground biomass can be harvested with subsequent resprouting without disturbance of the site [113]. However, the cost for planting trees is high and the growth rate is low.

To achieve a stable persistent cover it is important to use a mixed culture, and combine grasses, shrubs and trees in revegetation programs of mining soils because they represent two functional types of plants with different roles in the improvement of mine soils. For a longer duration, as considered for most phytoremediation 
Table 2. Definition and main characteristics of phytoremediation processes [1] [23] [44] [54] [70] [83] [85] [87]-[96].

\begin{tabular}{|c|c|c|c|c|c|}
\hline Process & Definition & Process goal & Contaminants & Media & Selection criteria of plant species \\
\hline Phytoextraction & $\begin{array}{l}\text { Uptake of a } \\
\text { contaminant } \\
\text { by plant roots } \\
\text { from the } \\
\text { environment } \\
\text { and its } \\
\text { translocation } \\
\text { into } \\
\text { harvestable } \\
\text { plant } \\
\text { biomass }\end{array}$ & $\begin{array}{l}\text { Contaminant } \\
\text { extraction } \\
\text { and capture }\end{array}$ & $\begin{array}{l}\text { Organic and } \\
\text { inorganic } \\
\text { pollutants }\end{array}$ & $\begin{array}{ll}\text { - } & \text { Soils; } \\
\text { - } & \text { Sediments; } \\
\text { - } & \text { Water; } \\
\text { - } & \text { Sludges. }\end{array}$ & $\begin{array}{ll}\text { - } & \text { Tolerance to high concentrations } \\
\text { metals; } & \text { - } \\
\text { High metal-accumulation } \\
\text { capability; } \\
\text { - } \quad \text { Rapid growth rate; } \\
\text { - } \\
\text { Accumulation of trace elements in } \\
\text { the above ground parts; } \\
\text { - } \quad \text { Easy to harvest; } \\
\text { - } & \text { Extended root system for } \\
\text { exploring large soil volumes; } \\
\text { - } & \text { High translocation factor; } \\
\text { - } & \text { Easy agricultural management; } \\
\text { - } & \text { Good adaptation to prevailing } \\
& \text { environmental and climatic } \\
& \text { conditions; } \\
\text { - } & \text { Resistance to pathogens and pests; } \\
\text { - } & \text { Rrepulse herbivores to avoid food } \\
& \text { chain contamination. }\end{array}$ \\
\hline Phytostabilization & $\begin{array}{l}\text { Reduction of } \\
\text { mobility and } \\
\text { bioavailabilit } \\
\text { y of } \\
\text { pollutants in } \\
\text { environment } \\
\text { either by } \\
\text { physical or } \\
\text { chemical } \\
\text { effects }\end{array}$ & $\begin{array}{l}\text { Contaminant } \\
\text { containment }\end{array}$ & $\begin{array}{l}\text { Heavy metals; } \\
\text { Chlorinated } \\
\text { solvents }\end{array}$ & $\begin{array}{ll}\text { - } & \text { Soil; } \\
\text { - } & \text { Sediments; } \\
\text { - } & \text { Sludges. }\end{array}$ & $\begin{array}{l}\text { The ability to develop extended } \\
\text { and abundant root systems; } \\
\text { The ability to keep the } \\
\text { translocation of metals from roots } \\
\text { to shoots as low as possible; } \\
\text { - The capacity to retain the } \\
\text { contaminants in the roots or } \\
\text { rhizosphere (excluder mechanism) } \\
\text { to limit the spreading through the } \\
\text { food chain. }\end{array}$ \\
\hline Phytovolatilization & $\begin{array}{l}\text { The process } \\
\text { of absorption } \\
\text { of pollutants } \\
\text { by plants and } \\
\text { volatilization } \\
\text { into the } \\
\text { atmosphere } \\
\text { by the foliar } \\
\text { system }\end{array}$ & $\begin{array}{l}\text { Contaminant } \\
\text { extraction } \\
\text { from media } \\
\text { and release to } \\
\text { air }\end{array}$ & $\begin{array}{l}\text { Chlorinated } \\
\text { solvents; } \\
\text { Inorganic } \\
\text { compounds }\end{array}$ & $\begin{array}{ll}\text { - } & \text { Grouwndwat } \\
& \text { er } \\
\text { - } & \text { Soil } \\
\text { - } & \text { Sediments } \\
\text { - } & \text { Sludges }\end{array}$ & \\
\hline Rhizofiltration & $\begin{array}{l}\text { The use of } \\
\text { plant roots to } \\
\text { absorb or } \\
\text { adsorb } \\
\text { contaminants } \\
\text { that are in } \\
\text { solution } \\
\text { surrounding } \\
\text { the root zone }\end{array}$ & $\begin{array}{l}\text { Contaminant } \\
\text { extraction } \\
\text { and capture }\end{array}$ & $\begin{array}{l}\text { Heavy metals; } \\
\text { Ogranic } \\
\text { compounds }\end{array}$ & $\begin{array}{ll}\text { - } & \text { Surface } \\
\text { Waters; } \\
\text { - } & \text { Wastewaters. }\end{array}$ & $\begin{array}{ll}\text { - } & \text { Metal-resistant plants; } \\
\text { - } & \text { High adsorption surface; } \\
\text { - } & \text { Tolerance of Hypoxia; } \\
\text { - } & \text { Terrestrial plants are preferred } \\
& \text { because they have a fibrous and } \\
\text { much longer root system, } \\
\text { increasing the amount of root } \\
\text { area. }\end{array}$ \\
\hline
\end{tabular}

processes, it cannot be expected to clean up the soil only by one plant species used exclusively in monoculture [114]. Grasses, with their highly developed root system, can stabilize the soils and reduce erosion, while legumes can add nitrogen to the soil, preparing the establishment of other plant species typical of later stages of succession [115]-[117].

Perennial grasses develop a large plant biomass in a relatively short time and are recognized as heavy metal tolerant biosystems, accumulating high levels of these elements [54]. However, the shorter growing period of the seasonal flowering plants is a better option in phytoremediation over perennial plants, as it can be harvested yearly or seasonally, and the area can be replanted with subsequent seasonal flowering plants [109].

For phytoremediation, it is better to use plant species adapted to the climatic and soil conditions of the 
Table 3. Advantages and limitations of phytoremediation [11] [12] [23] [54] [56] [84] [97] [98].

\begin{tabular}{cc|}
\hline Advantages & Limitations \\
\hline Cost & Time \\
\hline
\end{tabular}

- $\quad$ Low capital and operating cost;

- $\quad$ Metal recycling provides further economic advantages.

- $\quad$ Low capital and operating cost;

- $\quad$ Metal recycling provides further economic advantages.
- $\quad$ Slower compared to other techniques and seasonally dependent;

- $\quad$ Most of the hyperaccumulators are slow growers.

- $\quad$ Slower compared to other techniques and seasonally dependent;

- Most of the hyperaccumulators are slow growers.

Performance

- Permanent treatment solution;

- Capable of remediating bioavailable fraction of contaminants;

- Capable of mineralizing organics;

- The potential to treat sites polluted with more than one type of pollutant;

- $\quad$ It is restricted to the rooting depth of remediative plants;

- Highly-specialized personnel not required;

- $\quad$ Can be used for site investigation or after closure.

\section{Not capable of $100 \%$ reduction}

High contaminant concentration may be toxic to plants; Soil phytoremediation is applicable only to surface soils; Restricted to sites with low contaminant concentrations; Requires technical strategy, expert project designers with field experience that choose the proper species and cultivars for particular metals and regions.

Application

- In situ application avoids excavation and transport of polluted media;

- $\quad$ Relatively easy to implement.

- $\quad$ The presence of multiple types of heavy metals and organic contaminants may pose a challenge;

- Climatic conditions are a limiting factor.

Impact in the environment and population

- $\quad$ Reduce the risk of spreading the contamination; Eliminate secondary air or water borne Wastes; Public acceptance due to aesthetic reasons.
Metals can be washed by rain and transported back into the soil du the decomposition of plant biomass;

- $\quad$ The use of invasive, non-native species can affect biodiversity;

- $\quad$ Risk of food chain contamination in case of mismanagement and lack of proper care.

area to be de-polluted [54] [86] [118]. Use of indigenous plant species is generally favoured because they show tolerance to imposed stress conditions, require less maintenance and present fewer environmental and human risks than non-native or genetically altered species [119]. However, particular non- native plant may work best remediation of specific contaminant and can be safely used under circumstances where the possibility of invasive behaviour has been eliminated [120].

\section{Conclusion}

Phytoremediation is a promising green technology that can be used to remediate heavy metal contaminated soils. In developing countries like Morocco, this technology can provide low-cost solution to remediate contaminated area, especially abandoned industrial sites (mines and landfills). The complexity of factors that control the efficiency of this technique, such as soils properties, plant species and climatic conditions, fact that more researches need to be conducted. More species that have remediative abilities need to be identified, especially the plants that can contribute to social and economic development of local population, such as industrial species. Also, in the future, research should focus on developing agricultural techniques to enhance phytoremediation efficiency and reduce time and cost of heavy metal removal from soils. The valorization of some industrial residue in order to increase the heavy metal phytoavailability can be investigated. 
Table 4. The advantages and limitations of various mechanisms of phytoremediation [54] [85] [89] [99]-[102].

\begin{tabular}{|c|c|c|}
\hline Mechanisms & Advantages & Limitation \\
\hline Phytoextraction & $\begin{array}{l}\text { - The cost of phytoextraction is fairly } \\
\text { Inexpensive; } \\
\text { - The contaminant is permanently removed } \\
\text { from the soil ; } \\
\text { - The amount of waste material that must be } \\
\text { disposed of is substantially decreased ( up to } \\
\text { 95\%); } \\
\text { - The contaminant can be recycled from the } \\
\text { contaminated plant biomass. }\end{array}$ & $\begin{array}{l}\text { - Metal hyperaccumulators are generally } \\
\text { slow-growing with a small biomass and shallow } \\
\text { root systems; } \\
\text { - Plant biomass must be harvested and removed, } \\
\text { followed by metal reclamation or proper disposal } \\
\text { of the biomass; } \\
\text { - Metals may have a phytotoxic effect. }\end{array}$ \\
\hline Phytostabilization & $\begin{array}{l}\text { - The disposal of hazardous material or biomass } \\
\text { is not required ; } \\
\text { - Very effective when rapid immobilization is } \\
\text { needed to preserve ground and surface } \\
\text { waters ; } \\
\text { - The presence of plants also reduces soil } \\
\text { erosion and decreases the amount of water } \\
\text { available in the system; } \\
\text { - Soil removal is unnecessary; } \\
\text { - It has a lower cost and is less disruptive than } \\
\text { other more-vigorous soil remedial } \\
\text { technologies; } \\
\text { - Revegetation enhances ecosystem restoration; } \\
\text { - Method with good results in prevention of } \\
\text { acid mine discharges and metal stabilization. }\end{array}$ & $\begin{array}{l}\text { - The contaminants remain in place; } \\
\text { - The vegetation and soil may require long-term } \\
\text { maintenance to prevent rerelease of the } \\
\text { contaminants and future leaching; } \\
\text { - Vegetation may require extensive fertilization or } \\
\text { soil modification using amendments; } \\
\text { - Plant uptake of metals and translocation to the } \\
\text { aboveground portion must be avoided; } \\
\text { - The root zone, root exudates, contaminants, and } \\
\text { soil amendments must be monitored to prevent an } \\
\text { increase in metal solubility and leaching; } \\
\text { - Phytostabilization might be considered to only be } \\
\text { an interim measure; } \\
\text { - Contaminant stabilization might be due primarily } \\
\text { to the effects of soil amendments, with plants } \\
\text { only contributing to stabilization by decreasing } \\
\text { the amount of water moving through the soil and } \\
\text { by physically stabilizing the soil against erosion. }\end{array}$ \\
\hline Phytovolatilization & $\begin{array}{l}\text { - The contaminant, mercuric ion, may be } \\
\text { transformed into a less toxic substance; } \\
\text { - Contaminants could be transformed to } \\
\text { less-toxic substances; } \\
\text { - Contaminants or metabolites released to the } \\
\text { atmosphere might be subject to more effective } \\
\text { or rapid natural degradation processes such as } \\
\text { photodegradation. }\end{array}$ & $\begin{array}{l}\text { - The contaminant or a hazardous metabolite might } \\
\text { be released into the atmosphere; } \\
\text { - The contaminant or a hazardous metabolite might } \\
\text { accumulate in vegetation and be passed on in } \\
\text { later products such as fruit or lumber; } \\
\text { - Low levels of metabolites have been found in } \\
\text { plant tissue. }\end{array}$ \\
\hline Rhizofiltration & $\begin{array}{l}\text { - The ability to use both terrestrial and aquatic } \\
\text { plants for either in situ or ex situ applications; } \\
\text { - Species other than hyperaccumulators may be } \\
\text { used; } \\
\text { - An ex situ system can be placed anywhere } \\
\text { because the treatment does not have to be at } \\
\text { the original location of contamination. }\end{array}$ & $\begin{array}{l}\text { - The constant need to adjust pH to obtain optimum } \\
\text { metals uptake; } \\
\text { - Plants may first need to be grown in a greenhouse } \\
\text { or nursery; } \\
\text { - Periodic harvesting and plant disposal are } \\
\text { required; } \\
\text { - Tank design must be well engineered; } \\
\text { - A good understanding of the chemical } \\
\text { speciation/interactions is needed; } \\
\text { - The chemical speciation and interaction of all } \\
\text { species in the influent have to be understood and } \\
\text { accounted for; } \\
\text { - Metal immobilization and uptake results from } \\
\text { laboratory and greenhouse studies might not be } \\
\text { achievable in the field. }\end{array}$ \\
\hline
\end{tabular}

\section{References}

[1] Subhashini, V. and Swamy, A.V.V.S. (2013) Phytoremediation of Pb and Ni Contaminated Soils Using Catharanthus roseus (L.). Universal Journal of Environmental Research and Technology, 3, 465-472.

[2] Barcelo, J. and Poschenrieder, C. (2003) Phytoremediation: Principles and Perspectives. Contributions to Science, 2, 333-334.

[3] Tica, D., Udovic, M. and Lestan, D. (2011) Immobilization of Potentially Toxic Metals Using Different Soil Amendments. Chemosphere, 85, 577-583. http://dx.doi.org/10.1016/j.chemosphere.2011.06.085

[4] Xu, M. and Lu, N. (2012) Research on Removing Heavy Metals From Mine Tailings. Disaster Advances, 5, 116-120. 
[5] Montinaro, S., Concas, A., Pisu, M. and Cao, G. (2012) Remediation of Heavy Metals Contaminated Soils by Ball Milling. Chemical Engineering Transactions, 28, 187-192.

[6] Jadia, C.D. and Fulekar, M.H. (2009) Phytoremediation of Heavy Metals: Recent Techniques. African Journal of Biotechnology, 8, 921-928.

[7] Danh, L.T., Truong, P., Mammucari, R., Tran, T. and Foster, N. (2009) Vetiver Grass, Vetiveria zizanioides: A Choice Plant for Phytoremediation of Heavy Metals and Organic Wastes. International Journal of Phytoremediation, 11, 664-691. http://dx.doi.org/10.1080/15226510902787302

[8] Ahmadpour, P., Ahmadpour, F., Mahmud, T.M.M., Abdu, A., Soleimani, M. and Hosseini Tayefeh, F. (2012) Phytoremediation of Heavy Metals: A Green Technology. African Journal of Biotechnology, 11, 14036-14043.

[9] Cunningham, S.D., Berti, W.R. and Huang, J.W. (1995) Phytoremediation of Contaminated Soils. Trends in Biotechnology, 13, 393-397. http://dx.doi.org/10.1016/S0167-7799(00)88987-8

[10] Cluis, C. (2004) Junk-Greedy Greens: Phytoremediation as a New Option for Soil Decontamination. BioTeach Journal, 2, 61-67.

[11] Ghosh, M. and Singh, S.P. (2005) A Review on Phytoremediation of Heavy Metals and Utilization of Its Byproducts. Applied Ecology and Environmental Research, 3, 1-18. http://dx.doi.org/10.15666/aeer/0301_001018

[12] Moosavi, S.G. and Seghatoleslami, M.J. (2013) Phytoremediation: A Review. Advance in Agriculture and Biology, 1, 5-11.

[13] Vaziri, A., Panahpour, E. and MirzaeeBeni, M.H. (2013) Phytoremediation: A Method for Treatment of Petroleum Hydrocarbon Contaminated Soils. International Journal of Farming and Allied Sciences, 2, 909-913.

[14] Jadia, C.D. and Fulekar, M.H. (2008) Phytoremediation: The Application of Vermicompost to Remove Zinc, Cadmium, Copper, Nickel and Lead by Sunflower Plant. Environmental Engineering and Management Journal, 7, 547-558.

[15] Ismail, S., Khan, F. and Zafar Iqbal, M. (2013) Phytoremediation: Assessing Tolerance of Tree Species against Heavy Metal (PB and CD) Toxicity. Pakistan Journal of Botany, 45, 2181-2186.

[16] Alloway, B.J. and Ayres, D.C. (1997) Chemical Principles of Environmental Pollution. Blackie Academic, London, 168.

[17] Adriano, D.C. (2001) Trace Elements in Terrestrial Environments: Biochemistry, Bioavailability and Risks of Metals. 2nd Edition, Springer-Verlag, New York. http://dx.doi.org/10.1007/978-0-387-21510-5

[18] Zovko, M. and Romic, M. (2011) Soil Contamination by Trace Metals: Geochemical Behavior as an Element of Risk Assessment. In: Dar, I.A., Ed., Earth and Environmental Sciences, InTech, Rijeka, 437-456.

[19] Wuana, R.A. and Okieimen, F.E. (2011) Heavy Metals in Contaminated Soils: A Review of Sources, Chemistry, Risks and Best Available Strategies for Remediation. Communications in Soil Science and Plant Analysis, 42, 111-122. http://dx.doi.org/10.5402/2011/402647

[20] Parizanganeh, A.H., Bijnavand, V., Zamani, A.A. and Hajabolfath, A. (2012) Concentration, Distribution and Comparison of Total and Bioavailable Heavy Metals in Top Soils of Bonab District in Zanjan Province. Open Journal of Soil Science, 2, 123-132. http://dx.doi.org/10.4236/ojss.2012.22018

[21] Dembitsky, V. (2003) Natural Occurrence of Arseno Compounds in Plants, Lichens, Fungi, Algal Species, and Microorganisms. Plant Science, 165, 1177-1192. http://dx.doi.org/10.1016/j.plantsci.2003.08.007

[22] Igwe, J.C. and Abia, A.A. (2006) A Bioseparation Process for Removing Heavy Metals from Waste Water Using Biosorbents. African Journal of Biotechnology, 5, 1167-1179.

[23] Ali, H., Khan, E. and Sajad, M.A. (2013) Phytoremediation of Heavy Metals-Concepts and Applications. Chemosphere, 91, 869-881. http://dx.doi.org/10.1016/j.chemosphere.2013.01.075

[24] Kaasalainen, M. and Yli-Halla, M. (2003) Use of Sequential Extraction to Assess Metal Partitioning in Soils. Environmental Pollution, 126, 225-233. http://dx.doi.org/10.1016/S0269-7491(03)00191-X

[25] Bolan, N., Naidu, R., Choppala, G., Park, J., Mora, M.L., Budianta, D. and Panneerselvam, P. (2010) Solute Interactions in Soils in Relation to the Bioavailability and Environmental Remediation of Heavy Metals and Metalloids. Pedologist, Vol., 1-18.

[26] Navarro, M.C., Perez-Sirvent, C., Martinez-Sanchez, M.J., Vidal, J., Tovar, P.J. and Bech, J. (2008) Abandoned Mine Sites as a Source of Contamination by Heavy Metals: A Case Study in a Semi-Arid Zone. Journal of Geochemical Exploration, 96, 183-193. http://dx.doi.org/10.1016/j.gexplo.2007.04.011

[27] Cempel, M. and Nikel, G. (2006) Nickel: A Review of Its Sources and Environmental Toxicology. Polish Journal of Environmental Studies, 15, 375-382.

[28] Gohre, V. and Paszkowski, U. (2006) Contribution of the Arbuscular Mycorrhizal Symbiosis to Heavy Metal Phytoremediation. Planta, 223, 1115-1122. http://dx.doi.org/10.1007/s00425-006-0225-0 
[29] Hall, J.L. (2002) Cellular Mechanisms for Heavy Metal Detoxification and Tolerance. Journal of Experimental Botany, 53, 1-11. http://dx.doi.org/10.1093/jexbot/53.366.1

[30] Djingova, R. and Kuleff, I. (2000) Instrumental Techniques for Trace Analysis. In: Vernet, J.P., Ed., Trace Elements: Their Distribution and Effects in the Environment, Elsevier Science Ltd., United Kingdom, 137-185. http://dx.doi.org/10.1016/S0927-5215(00)80008-9

[31] Gaur, A. and Adholeya, A. (2004) Prospects of Arbuscular Mycorrhizal Fungi in Phytoremediation of Heavy Metal Contaminated Soils. Current Science, 86, 528-534.

[32] Alloway, B.J. (1995) Heavy Metals in Soils. Second Edition, Blakie and Son, Glasgow, 368. http://dx.doi.org/10.1007/978-94-011-1344-1

[33] Zengin, F.K. and Munzuroglu, O. (2005) Effects of Some Heavy Metals on Content of Chlorophyll, Proline and Some Antioxidant Chemicals in Bean (Phaseolus vulgaris L.) Seedlings. Acta Biologica Cracoviensia Series Botanica, 47, 157-164.

[34] Ochonogor, R.O. and Atagana, H.I. (2014) Phytoremediation of Heavy Metal Contaminated Soil by Psoralea pinnata. International Journal of Environmental Science and Development, 5, 440-443. http://dx.doi.org/10.7763/IJESD.2014.V5.524

[35] Gardea-Torresdey, J.L., Peralta-Videa, J.R., de la Rosa, G. and Parsons, J.G. (2005) Phytoremediation of Heavy Metals and Study of the Metal Coordination by X-Ray Absorption Spectroscopy. Coordination Chemistry Reviews, 249, 17971810. http://dx.doi.org/10.1016/j.ccr.2005.01.001

[36] Schmidt, U. (2003) Enhancing Phytoextraction: The Effects of Chemical Soil Manipulation on Mobility, Plant Accumulation, and Leaching of Heavy Metals. Journal of Environmental Quality, 32, 1939-1954. http://dx.doi.org/10.2134/jeq2003.1939

[37] Oh, K., Cao, T., Li, T. and Cheng, H. (2014) Study on Application of Phytoremediation Technology in Management and Remediation of Contaminated Soils. Journal of Clean Energy Technologies, 2, 216-220. http://dx.doi.org/10.7763/JOCET.2014.V2.126

[38] Rylott, E.L. and Bruce, N.C. (2008) Plants Disarm Soil: Engineering Plants for the Phytoremediation of Explosives. Trends in Biotechnology, 27, 73-81. http://dx.doi.org/10.1016/j.tibtech.2008.11.001

[39] Boonyapookana, B., Parkpian, P., Techapinyawat, S., Delaune, R.D. and Jugsujinda, A. (2005) Phytoaccumulation of Lead by Sunflower (Helianthus annus), Tobacco (Nicotiana tabacum), and Vetiver (Vetiveria zizanioides). Journal of Environmental Science and Health, 40, 117-137. http://dx.doi.org/10.1081/ESE-200033621

[40] Dwivedi, G.K., Upadhyay, S.K., Mishra, A.K. and Singh, A.K. (2014) Hyper Accumulation of Cadmium in Solanum nigrum L. and Their Effects on Phyto-Chemicals and Antioxidant Enzymatic Activities. International Journal of Pharmaceutical Sciences and Research, 5, 1424-1430.

[41] Frausto da Silva, J.J.R. and Williams, R.J.P. (2001) The Biological Chemistry of the Elements: The Inorganic Chemistry of Life. Oxford University Press, Oxford, 584 p.

[42] Kabata-Pendias, A. and Pendias, H. (2001) Trace Elements in Soils and Plants. 3rd Edition, CRC Press, Boca Raton, $403 \mathrm{p}$.

[43] Kuzovkina, Y.A., Knee, M. and Quigley, M.F. (2004) Cadmium and Copper Uptake and Translocation in Five Willow (Salix L.) Species. International Journal of Phytoremediation, 6, 269-287. http://dx.doi.org/10.1080/16226510490496726

[44] Vamerali, T., Bandiera, M. and Mosca, G. (2010) Field Crops for Phytoremediation of Metal-Contaminated Land: A Review. Environmental Chemistry Letters, 8, 1-17. http://dx.doi.org/10.1007/s10311-009-0268-0

[45] Wierzbicka, M. and Obidzinska, J. (1998) The Effect of Lead on Seed Imbibition and Germination in Different Plant Species. Plant Science, 137, 155-171. http://dx.doi.org/10.1016/S0168-9452(98)00138-1

[46] Semple, K.T., Morriss, A.W.J. and Paton, G.I. (2003) Bioavailability of Hydrophobic Contaminants in Soils: Fundamental Concepts and Techniques for Analysis. European Journal of Soil Science, 54, 809-818. http://dx.doi.org/10.1046/j.1351-0754.2003.0564.x

[47] Siebielec, G., Stuczyński, T. and Korzeniowska-Puculek, R. (2006) Metal Bioavailability in Long-Term Contaminated Tarnowskie Gory Soils. Polish Journal of Environmental Studies, 15, 121-129.

[48] Chang, Y.T., Hseu, Z.Y. and Zehetner, F. (2014) Evaluation of Phytoavailability of Heavy Metals to Chinese Cabbage (Brassica chinensis L.) in Rural Soils. Scientific World Journal, 2014, Article ID: 309396. http://dx.doi.org/10.1155/2014/309396

[49] Smical, A.I., Hotea, V., Oros, V., Juhasz, J. and Pop, E. (2008) Studies on Transfer and Bioaccumulation of Heavy Metals from Soil into Lettuce. Environmental Engineering and Management Journal, 7, 609-615.

[50] Kamnev, A.A. and van der Lelie, D. (2000) Chemical and Biological Parameters as Tools to Evaluate and Improve 
Heavy Metal Phytoremediation. Bioscience Reports, 20, 239-258. http://dx.doi.org/10.1023/A:1026436806319

[51] Lombi, E., Zhao, F.J., Dunham, S.J. and MacGrath, S.P. (2001) Phytoremediation of Heavy Metal Contaminated Soils: Natural Hyperaccumulation versus Chemically Enhanced Phytoextraction. Journal of Environmental Quality, 30, 19191926. http://dx.doi.org/10.2134/jeq2001.1919

[52] Farid, M., Ali, S., Shakoor, M.B., Bharwana, S.A., Rizvi, H., Ehsan, S., Tauqeer, H.M., Iftikhar, U. and Hannan, F. (2013) EDTA Assisted Phytoremediation of Cadmium, Lead and Zinc. International Journal of Agronomy and Plant Production, 4, 2833-2846.

[53] Peijnenburg, W.J.G.M. and Jager, T. (2003) Monitoring Approaches to Assess Bioaccessibility and Bioavailability of Metals: Matrix Issues. Ecotoxicology and Environmental Safety, 56, 63-77. http://dx.doi.org/10.1016/S0147-6513(03)00051-4

[54] Elekes, C.C. (2014) Eco-Technological Solutions for the Remediation of Polluted Soil and Heavy Metal Recovery. In: Hernández-Soriano, M.C., Ed., Environmental Risk Assessment of Soil Contamination, InTech, Rijeka, 309-335. http://dx.doi.org/10.5772/57314

[55] Dzombak, D.A. and Morel, F.M.M. (1987) Adsorption of Inorganic Pollutants in Aquatic Systems. Journal of Hydraulic Engineering, 113, 430-475. http://dx.doi.org/10.1061/(ASCE)0733-9429(1987)113:4(430)

[56] Saxena, P.K., Krishnaraj, S., Dan, T., Perras, M.R. and Vettakkoruma-Kankav, N.N. (1999) Phytoremediation of Metal Contaminated and Polluted Soils. In: Prasad, M.N.V. and Hagemeyer, J., Eds., Heavy Metal Stress in Plants-From Molecules to Ecosystems, Springer Verlag, Heidelberg, 305-329. http://dx.doi.org/10.1007/978-3-662-07745-0_14

[57] Dinev, N., Banov, M. and Nikova, I. (2008) Monitoring and Risk Assessment of Contaminated Soils. General and Applied Plant Physiology, 34, 389-396.

[58] Evanko, C.R. and Dzombak, D.A. (1997) Remediation of Metals-Contaminated Soils and Groundwater. Technology Evaluation Report, 61 p.

[59] Deneux-Mustin, S., Roussel-Debet, S., Mustin, C., Henner, P., Munier-Lamy, C., Colle, C., Berthelin, J., GarnierLaplace, J. and Leyval, C. (2003) Mobilité et transfert racinaire des éléments en traces: Influence des microorganismes du sol. TEC \& DOC, Paris.

[60] Takac, P., Szabova, T., Kozakova, L. and Benkova, M. (2009) Heavy Metals and Their Bioavailability from Soils in the Long-Term Polluted Central Spis Region of SR. Plant, Soil and Environment, 55, 167-172.

[61] Mahmood, T. (2010) Phytoextraction of Heavy Metals-The Process and Scope for Remediation of Contaminated Soils. Soil \& Environment, 29, 91-109.

[62] Sherene, T. (2010) Mobility and Transport of Heavy Metals in Polluted Soil Environment. Biological Forum—An International Journal, 2, 112-121.

[63] Singh, J. and Kalamdhad, A.S. (2013) Chemical Speciation of Heavy Metals in Compost and Compost Amended Soil — A Review. International Journal of Environmental Engineering Research, 2, 27-37.

[64] Gupta, A.K. and Sinha, S. (2007) Phytoextraction Capacity of the Plants Growing on Tannery Sludge Dumping Sites. Bioresource Technology, 98, 1788-1794. http://dx.doi.org/10.1016/j.biortech.2006.06.028

[65] Yobouet, Y.A., Adouby, K., Trokourey, A. and Yao, B. (2010) Cadmium, Copper, Lead and Zinc Speciation in Contaminated Soils. International Journal of Engineering Science and Technology, 2, 802-812.

[66] Fijalkowski, K., Kacprzak, M., Grobelak, A. and Placek, A. (2012) The Influence of Selected Soil Parameters on the Mobility of Heavy Metals in Soils. Inzynieria i Ochrona Srodowiska, 5, 81-92.

[67] Olaniran, A.O., Balgobind, A. and Pillay, B. (2013) Bioavailability of Heavy Metals in Soil: Impact on Microbial Biodegradation of Organic Compounds and Possible Improvement Strategies. International Journal of Molecular Sciences, 14, 10197-10228. http://dx.doi.org/10.3390/ijms140510197

[68] Brown, S.L., Henry, C.L., Chaney, R., Compton, H. and De Volder, P.S. (2003) Using Municipal Biosolids in Combination with Other Residuals to Restore Metal-Contaminated Mining Areas. Plant Soil, 249, 203-215. http://dx.doi.org/10.1023/A:1022558013310

[69] Romic, M. (2012) Bioavailability of Trace Metals in Terrestrial Environment: Methodological Issues. European Chemical Bulletin, 1, 489-493.

[70] Alkorta, I., Hernandez-Allica, J., Becerril, J.M., Amezaga, I., Albizu, I. and Garbisu, C. (2004) Recent Findings on the Phytoremediation of Soils Contaminated with Environmentally Toxic Heavy Metals and Metalloids Such as Zinc, Cadmium, Lead, and Arsenic. Reviews in Environmental Science and Bio/Technology, 3, 71-90. http://dx.doi.org/10.1023/B:RESB.0000040059.70899.3d

[71] Mallmann, F.J.K., Rheinheimer, D.S., Ceretta, C.A., Cella, C., Minella, J.P.G., Guma, R.L., Filipovic, V., Oort, F. and Simunek, J. (2014) Soil Tillage to Reduce Surface Metal Contamination-Model Development and Simulations of Zinc and Copper Concentration Profiles in a Pig Slurry-Amended Soil. Agriculture, Ecosystems and Environment, 196, 59- 
68. http://dx.doi.org/10.1016/j.agee.2014.06.024

[72] Degryse, F., Waegeneers, N. and Smolders, E. (2007) Labile Lead in Polluted Soils Measured by Stable Isotope Dilution. European Journal of Soil Science, 58, 1-7. http://dx.doi.org/10.1111/j.1365-2389.2005.00788.x

[73] Shenker, M., Fan, T.W.M. and Crowley, D.E. (2001) Phytosiderophores Influence on Cadmium Mobilization and Uptake by Wheat and Barley Plants. Journal of Environmental Quality, 30, 2091-2098. http://dx.doi.org/10.2134/jeq2001.2091

[74] Jones, D.L., Hodge, A. and Kuzyakov, Y. (2004) Plant and Mycorrhizal Regulation of Rhizodeposition. New Phytologist, 163, 459-480. http://dx.doi.org/10.1111/j.1469-8137.2004.01130.x

[75] Fitz, W.J. and Wenzel, W.W. (2002) Arsenic Transformations in the Soil-Rhizosphere-Plant System: Fundamentals and Potential Application to Phytoremediation. Journal of Biotechnology, 99, 259-278. http://dx.doi.org/10.1016/S0168-1656(02)00218-3

[76] Wenzel, W.W., Bunkowski, M., Puschenreiter, M. and Horak, O. (2003) Rhizosphere Characteristics of Indigenously Growing Nickel Hyperaccumulator and Tolerant Plants on Serpentine Soil. Environmental Pollution, 123, 131-138. http://dx.doi.org/10.1016/S0269-7491(02)00341-X

[77] Fuentes, A., Lloren, M., Saez, J., Soler, A., Aguilar, M.I., Ortuno, J.F. and Meseguer, V.F. (2004) Simple and Sequential Extractions of Heavy Metals from Different Sewage Sludge. Chemosphere, 54, 1039-1047. http://dx.doi.org/10.1016/j.chemosphere.2003.10.029

[78] Chaney, R.L. and Oliver, D.P. (1996) Sources, Potential Adverse Effects and Remediation of Agricultural Soil Contaminants. Proceedings of the First Australasia-Pacific Conference on Contaminants and Soil Environment in the Australasia-Pacific Region, Adelaide, 18-23 February 1996, 323-359. http://dx.doi.org/10.1007/978-94-009-1626-5_11

[79] Pichtel, J. and Anderson, M. (1997) Trace Metal Bioavailability in Municipal Solid Waste and Sewage Sludge Composts. Bioresource Technology, 60, 223-229. http://dx.doi.org/10.1016/S0960-8524(97)00025-4

[80] Nouri, J., Khorasani, N., Lorestani, B., Karami, M., Hassani, A.H. and Yousefi, N. (2009) Accumulation of Heavy Metals in Soil and Uptake by Plant Species with Phytoremediation Potential. Environmental Earth Sciences, 59, 315323. http://dx.doi.org/10.1007/s12665-009-0028-2

[81] Hamon, R.E., Wundke, J., McLaughlin, M.J. and Naidu, R. (1997) Availability of Zinc and Cadmium to Different Plant Species. Australian Journal of Soil Research, 35, 1267-1277. http://dx.doi.org/10.1071/S97052

[82] Hamon, R. and McLaughlin, M. (2003) Food Crop Edibility on the Ok Tedi/Fly River Flood Plain. Report for OK, 66 p.

[83] United States Environmental Protection Agency (2001) Brownfields Technology Primer: Selecting and Using Phytoremediation for Site Cleanup. USEPA, Washington DC, 46 p.

[84] Paz-Ferreiro, J., Lu, H., Fu, S., Mendez, A. and Gasco, G. (2014) Use of Phytoremediation and Biochar to Remediate Heavy Metal Polluted Soils: A Review. Solid Earth, 5, 65-75. http://dx.doi.org/10.5194/se-5-65-2014

[85] United States Environmental Protection Agency (2000) Introduction to Phytoremediation. USEPA, Cincinnati.

[86] Pivetz, P. (2001) Phytoremediation of Contaminated Soil and Ground Water at Hazardous Waste Sites. EPA/540/S-01/ 500, United States Environmental Protection Agency (EPA), Washington DC, 36 p.

[87] Dushenkov, V., Nanda Kumar, P.B.A., Motto, H. and Rakin, I. (1995) Rhizofiltration: The Use of Plants to Remove Heavy Metals from Aqueous Streams. Environmental Science \& Technology, 29, 1239-1245. http://dx.doi.org/10.1021/es00005a015

[88] Horne, A.J. (2000) Phytoremediation by Constructed Wetlands. In: Terry, N. and Banuelos, G., Eds., Phytoremediation of Contaminated Soils and Waters, CRC Press LLC, Boca Raton, 13-39.

[89] Kumar, P.B.A., Dushenkov, V., Motto, H. and Raskin, I. (1995) Phytoextraction: The Use of Plants to Remove Heavy Metals from Soils. Environmental Science \& Technology, 29, 1232-1238. http://dx.doi.org/10.1021/es00005a014

[90] Pulford, I.D. and Watson, C. (2003) Phytoremediation of Heavy Metal-Contaminated Land by Trees-A Review. Environment International, 29, 529-540. http://dx.doi.org/10.1016/S0160-4120(02)00152-6

[91] Raskin, I. and Ensley, B.D. (2000) Phytoremediation of Toxic Metals: Using Plants to Clean up the Environment. John Wiley \& Sons, Inc., New York, 53-70.

[92] Salt, D.E., Smith, R.D. and Raskin, I. (1998) Phytoremediation. Annual Review of Plant Physiology and Plant Molecular Biology, 49, 643-668. http://dx.doi.org/10.1146/annurev.arplant.49.1.643

[93] Vangronsveld, J., Assche, F.V. and Clijsters, H. (1995) Reclamation of a Bare Industrial Area Contaminated by Non-Ferrous Metals: In Situ Metal Immobilization and Revegetation. Environmental Pollution, 87, 51-59. http://dx.doi.org/10.1016/S0269-7491(99)80007-4

[94] Mendez, M.O. and Maier, R.M. (2008) Phytostabilization of Mine Tailings in Arid and Semiarid Environments-An 
Emerging Remediation Technology. Environmental Health Perspectives, 116, 278-283. http://dx.doi.org/10.1289/ehp.10608

[95] Vangronsveld, J., Herzig, R., Weyens, N., Boulet, J., Adriaensen, K., Ruttens, A., Thewys, T., Vassilev, A., Meers, E., Nehnevajova, E., van der Lelie, D. and Mench, M. (2009) Phytoremediation of Contaminated Soils and Groundwater: Lessons from the Field. Environmental Science and Pollution Research International, 16, 765-794.

[96] Tangahu, B.V., Abdullah, S.R.S., Basri, H., Idris, M., Anuar, N. and Mukhlisin, M. (2011) A Review on Heavy Metals (As, $\mathrm{Pb}$, and $\mathrm{Hg}$ ) Up-Take by Plants through Phytoremediation. International Journal of Chemical Engineering, 2011, Article ID: 939161.

[97] Hegedus, A., Jakabova, S. and Simon, L. (2009) Induced Phytoextraction of Lead from Contaminated Soil. Acta Universitatis Sapientiae, Agriculture and Environment, 1, 116-122.

[98] Mudgal, V., Madaan, N. and Mudgal, A. (2010) Heavy Metals in Plants: Phytoremediation: Plants Used to Remediate Heavy Metal Pollution. Agriculture and Biology Journal of North America, 1, 40-46.

[99] Ashraf, M.A., Maah, M.J. and Yusoff, I. (2013) Evaluation of Natural Phytoremediation Process Occurring at Extin Mining Catchment. Chiang Mai Journal of Science, 40, 198-213.

[100] Henry, J.R. (2000) An Overview of the Phytoremediation of Lead and Mercury. National Network of Environmental Management Studies (NNEMS) Report, Washington DC, 55 p.

[101] ITRC, Interstate Technology and Regulatory Corporation Work Group (1997) Phytotechnology Technical and Regulatory Guidance Document. ITCR and Phytotechnologies Teams, Washington DC, 124 p.

[102] Newman, L.A., Strand, S.E., Choe, N., Duffy, J., Ekuan, G., Ruszaj, M., Shurtleff, B.B., Wilmoth, J., Heilman, P. and Gordon, M.P. (1997) Uptake and Biotransformation of Trichloroethylene by Hybrid Poplars. Environmental Science \& Technology, 31, 1062-1067. http://dx.doi.org/10.1021/es960564w

[103] Sharma, H.D. and Reddy, K.R. (2004) Geoenvironmental Engineering: Site Remediation, Waste Containment and Emerging Waste Management Technologies. John Wiley and Sons, New York.

[104] Shu, W.S., Xia, H.P. and Zhang, Z.Q. (2002) Use of Vetiver and Three Other Grasses for Revegetation of Pb/Zn Mine Tailings: Field Experiment. International Journal of Phytoremediation, 4, 47-57. http://dx.doi.org/10.1080/15226510208500072

[105] Malik, R.N., Husain, S.Z. and Nazir, I. (2010) Heavy Metal Contamination and Accumulation in Soil and Wild Plant Species from Industrial Area of Islamabad, Pakistan. Pakistan Journal of Botany, 42, 291-301.

[106] Hubbard, C.E. (1954) Grasses: A Guide to Their Structure, Identification, Uses, and Distribution in the British Isles. Penguin Books, London, 402 p.

[107] Xia, H.P., Ao, H.X., Liu, S.Z. and He, D.Q. (1999) Application of the Vetiver Eco-Engineering for the Prevention of Highway Slippage in South China. Proceedings of the 1st Asia-Pacific Conference on Ground and Water Bioengineering for Erosion Control and Slope Stabilization, Manila, 19-21 April 1999, 522-527.

[108] Ye, Z.H., Wong, J.W.C. and Wong, M.H. (2000) Vegetation Response to Lime and Manure Compost Amendments on Acid Lead/Zinc Mine Tailings: A Greenhouse Study. Restoration Ecology, 8, 289-295. http://dx.doi.org/10.1046/j.1526-100x.2000.80041.x

[109] Sinha, S., Mishra, R.K., Sinam, G., Mallick, S. and Gupta, A.K. (2013) Comparative Evaluation of Metal Phytoremediation Potential of Trees, Grasses and Flowering Plants from Tannery Wastewater Contaminated Soil in Relation with Physico-Chemical Properties. Soil and Sediment Contamination: An International Journal, 22, 958-983.

[110] Garba, S.T., Osemeahon, A.S., Humphrey, M. and Barminas, J.T. (2012) Ethylene Diamine Tetraacetic Acid (EDTA)Assisted Phytoremediation of Heavy Metal Contaminated Soil by Eleusineindica L. Gearth. Journal of Environmental Chemistry and Ecotoxicology, 4, 103-109.

[111] Hamzah, A. and Priyadarshini, R. (2014) Identification of Wild Grass as Remediator Plant on Artisanal Gold Mine Tailing. Plant Science International, 1, 33-40. http://dx.doi.org/10.12735/psi.v1n1p33

[112] Tiedemann, A.R. and Klemmedson, J.O. (2004) Responses of Desert Grassland Vegetation to Mesquite Removal and Regrowth. Journal of Range Management, 57, 455-465. http://dx.doi.org/10.2307/4003974

[113] Stomp, A.M., Han, K.H., Wilbert, S., Gordon, M.P. and Cunningham, S.D. (1994) Genetic Strategies for Enhancing Phytoremediation. Annals of the New York Academy of Sciences, 1, 481-491. http://dx.doi.org/10.1111/j.1749-6632.1994.tb47418.x

[114] Cechmankova, J., Vacha, R., Skala, J. and Havelkova, M. (2011) Heavy Metals Phytoextraction from Heavily and Moderately Contaminated Soil by Field Crops Grown in Monoculture and Crop Rotation. Soil and Water Research, 6, 120-130.

[115] Kidd, P., Barcelo, J., Bernal, M.P., Navari-Izzo, F., Poschenrieder, C., Shilev, S., Clemente, R. and Monterroso, C. (2009) Trace Element Behaviour at the Root-Soil Interface: Implications in Phytoremediation. Environmental and Ex- 
perimental Botany, 67, 243-259. http://dx.doi.org/10.1016/j.envexpbot.2009.06.013

[116] Sanchez, J.E., Willson, T.C., Kizilkaya, K., Parker, E. and Harwood, R.R. (2001) Enhancing the Mineralizable Nitrogen Pool through Substrate Diversity in Long Term Cropping Systems. Soil Science Society of America Journal, 65, 1442-1447. http://dx.doi.org/10.2136/sssaj2001.6551442x

[117] Carvalho, A., Nabais, C., Roiloa, S.R. and Rodriguez-Echeverria, S. (2013) Revegetation of Abandoned Copper Mines: The Role of Seed Banks and Soil Amendments. Web Ecology, 13, 69-77. http://dx.doi.org/10.5194/we-13-69-2013

[118] Tordoff, G.M., Baker, A.J.M. and Willis, A.J. (2000) Current Approaches to the Revegetation and Reclamation of Metalliferous Mine Wastes. Chemosphere, 41, 219-228. http://dx.doi.org/10.1016/S0045-6535(99)00414-2

[119] Compton, H.R., Prince, G.R., Fredericks, S.C. and Gussman, C.D. (2003) Phytoremediation of Dissolved Phase Organic Compounds: Optimal Site Considerations Relative to Field Case Studies. Remediation, 13, 21-37. http://dx.doi.org/10.1002/rem.10072

[120] United States Environmental Protection Agency, USEPA (2000) Electrokinetic and Phytoremediation in Situ Treatment of Metal-Contaminated Soil: State-of-the-Practice. Draft for Final Review. EPA/542/R-00/XXX. US Environmental Protection Agency, Office of Solid Waste and Emergency Response Technology Innovation Office, Washington DC. 